\title{
Emotional and cognitive changes in chronic kidney disease
}

\author{
Duk-Soo Kim ${ }^{1}$, Seong-Wook Kim² ${ }^{2}$, and Hyo-Wook Gil ${ }^{3}$
}

\begin{abstract}
${ }^{1}$ Department of Anatomy, Soonchunhyang University College of Medicine, Cheonan; ${ }^{2}$ Graduate School of New Drug Discovery \& Development, Chungnam National University, Daejeon; ${ }^{3}$ Department of Internal Medicine, Soonchunhyang University Cheonan Hospital, Cheonan, Korea
\end{abstract}

Received : November 1, 2021

Accepted: January 2, 2022

\section{Correspondence to}

Hyo-Wook Gil, M.D.

Department of Internal

Medicine, Soonchunhyang

University Cheonan Hospital, 31

Suncheonhyang 6-gil, Dongnam-

gu, Cheonan 31151, Korea

Tel: +82-41-570-3671

Fax: +82-41-574-5762

E-mail: hwgil@schmc.ac.kr

https://orcid.org/0000-0003-2550-

2739

This manuscript was contributed by The Korean Society of Nephrology.
Chronic kidney disease (CKD) leads to cognitive impairment and emotional changes. However, the precise mechanism underlying the crosstalk between the kidneys and the nervous system is not fully understood. Inflammation and cerebrovascular disease can influence the development of depression in CKD. CKD is one of the strongest risk factors for cognitive impairment. Moreover, cognitive impairment occurs in CKD as patients experience the dysregulation of several brain functional domains due to damage caused to multiple cortical regions and to subcortical modulatory neurons. The differences in structural brain changes between CKD and non-CKD dementia may be attributable to the different mechanisms that occur in CKD. The kidney and brain have similar anatomical vascular systems, which may be susceptible to traditional risk factors. Vascular factors are assumed to be involved in the development of cognitive impairment in patients with CKD. Vascular injury induces white matter lesions, silent infarction, and microbleeds. Uremic toxins may also be directly related to cognitive impairment in CKD. Many uremic toxins, such as indoxyl sulfate, are likely to have an impact on the central nervous system. Further studies are required to identify therapeutic targets to prevent changes in the brain in patients with CKD.

Keywords: Kidney failure, chronic; Depressive disorder; Cognitive dysfunction; Uremia; Brain

\section{INTRODUCTION}

Chronic kidney disease (CKD) is a critical health burden worldwide. The overall prevalence rate of CKD in Korea is $8.2 \%$ [1]. A number of risk factors, including diabetes, hypertension, and hyperlipidemia, are responsible for the progression of CKD and cardiovascular events [2,3]. Moreover, CKD itself is one of the strongest risk factors for cardiovascular events. These risk factors lead to endothelial cell injury, which eventually results in end organ damage [4]. Recent studies have examined the mechanism of the crosstalk between the kidney and other organs $[5,6]$. Kidney injury can adversely affect the function and induce pathological changes in the gut, lungs, heart, brain, and the immune system [7-9].

Under normal physiological conditions, homeostasis is maintained by the communication between the kidney and the central nervous system (CNS). For example, under normal physiological conditions, systemic changes in osmolarity are detected by osmoreceptors in the CNS. When osmolarity is high, vasopressin is secreted from the hypothalamus and the posterior region of the pituitary gland. Vasopressin increases the number of aquaporin 2 channels in the apical membrane and enhances the reabsorption of water in 
the kidney. The brain and nervous system are affected by pathological conditions in the kidney. Recent studies have shown that CKD and acute kidney injury adversely affect the structure and function of the brain and the nervous system [10-12]. However, there is still no consensus regarding the precise mechanism underlying the crosstalk between the kidney and the nervous system.

The neurological complications in patients with CKD are related to the peripheral nervous system and the CNS [13]. The prevalence of peripheral neuropathy is higher in patients with CKD than in the population with normal kidney function. Peripheral neuropathy includes myopathy, somatic neuropathy, and cranial neuropathy (olfactory, visual, and auditory nerves). CNS complications can be divided into cortical and subcortical disorders, and include cognitive disorders (encephalopathy, cognitive decline), vascular disorders (infarction, microbleeding, multifocal ischemia, posterior reversible encephalopathy), movement disorders (dystonia, chorea, tremor, reticular myoclonus), and sleep disorders (restless legs syndrome, sleep apnea) $[10,13,14]$.

The severity of cognitive dysfunction varies from mild cognitive impairment to severe dementia, which can prevent patients from independently carrying out activities of daily living. Some CKD patients also suffer from cognitive dysfunction. The prevalence of depression is about three times higher in patients with CKD than the general population. Some studies have suggested that CKD patients have elevated risks of developing depression, dementia, and cognitive impairment $[11,15,16]$. In this review, we discuss the interactions between the kidney and the brain in CKD patients, focusing on the possible mechanisms that may contribute to neurological disorders in these patients.

\section{ANXIETY AND DEPRESSION IN CKD}

The prevalence rates of fatigue, depression, and anxiety in patients with chronic conditions are around 1.5 to 4 times higher than in the general population $[12,17,18]$. Patients with CKD have prevalence rates of anxiety disorders and anxiogenic symptoms of $19 \%$ and $43 \%$, respectively [19]. Anxiety has a significant adverse effect on quality of life. Loosman et al. [20] reported that pre-dialysis CKD patients with elevated anxiety symptoms had $60 \%$ higher risks of mortality, hospitalization, and requiring dialysis than those without anxiety disorder. The most common risk factors of elevated anxiety symptoms are as follows: concomitant depression, reduced parathyroid hormone level, increased comorbidities, increased duration of hospitalization, decline in quality of life, and decreased vitality levels [19]. Persistently high or new-onset symptoms of anxiety are associated with reduced perceived social support in hemodialysis patients [21]. Regular screening for anxiety or depression as part of clinical care is therefore essential in patients with CKD and end-stage renal disease (ESRD). A number of anxiety screening tools and instruments, such as the Hospital Anxiety and Depression Scale (HADS), Beck Anxiety Inventory (BAI), and Generalized Anxiety Disorder 7 (GAD-7), have been used to evaluate the elevated anxiety symptoms of patients with CKD.

Depression is also common in the general population, with a lifetime risk of about 7\% [22]. Chronic disease increases the risk of depression because it increases economic burden, reduces quality of life, and impairs activities of daily living. Very few randomized clinical trials of treatment have focused on screening CKD patients for depression. Moreover, the sample sizes were small, and the clinical outcomes were surrogates. The prevalence of depression in CKD patients was reported to be $26.5 \%$ based on screening questionnaires and $21.4 \%$ in clinical interviews with psychiatrists [23]. The risk factors of depression in CKD patients are young age, female sex, Black race, low education level, low family income, unemployment, hypertension, smoking status, diabetes, and coronary artery disease. A bidirectional association between depression and chronic disease has been identified [11]. The Diagnostic and Statistical Manual of Mental Disorders (DSM) includes the standard set of criteria used to diagnose mental disorders. Moreover, DSM has also been used to diagnosis depression in CKD patients [24]. For screening of depression in patients with CKD and ESRD, the most commonly used questionnaires that need to be validated are the Patient Health Questionnaire (PHQ-9), Beck Depression Inventory (BDI), Center for Epidemiologic Studies Depression Scale (CESD) 14, and Quick Inventory of Depressive Symptomatology Self-Report (QIDS-SR) [25-27].

\section{MECHANISM OF DEPRESSION AND ANXIETY IN CKD}

The prevalence of depression is high in CKD patients due to several factors, including uremic toxins, psychosocial symp- 
toms, and economic challenges [8]. Although several mechanisms of depression have been reported in CKD patients, they could be broadly divided into behavioral and biological mechanisms. In this review, we focused on understanding the biological mechanisms.

Inflammation is frequently observed in CKD patients, which is related to adverse outcomes, including mortality [28,29]. Inflammation and depression have been suggested to show a bidirectional association in patients with chronic illness [30]. Other potential mechanisms include the development of comorbid cerebrovascular disease, which can also influence the incidence of depression in CKD patients. Moreover, cerebrovascular disease can increase the possibility of inflammation, which indirectly affects the mood of CKD patients. In clinical studies, it is difficult to establish a causal relationship between depression and CKD because many factors are involved. Experimental approaches can control for these factors, and help to understand the mechanism of depression in CKD patients. In a rodent CKD model, various behavioral tests were applied to evaluate sensorimotor function, mood, learning capacity, and memory. The results of these behavioral tests were validated and have been widely used in the literature describing how to evaluate neurological deficits in rodents (Table 1) [5,31-56].

The results of behavioral changes are disputed because of the diversity of CKD animal models, and the different time points for behavioral testing reflecting early or advanced stages of CKD [57-59]. Changes in the emotional behavior test were insufficient and ambiguous for CKD patients $[9,60,61]$. However, in our previous study in rats, we found that locomotor activity had declined in CKD rats [62]. Moreover, the time spent by the animals in the central zone of the open-field apparatus was reduced, indicating an increase in anxiety-related behaviors (Fig. 1) [62]. Many animal studies have shown that CKD itself causes changes in behavior, and leads to emotional and cognitive disorders (Table 2) [9,58,61-66].

Anxiety is described as the feeling of fear, uncertainty, helplessness, and apprehension that an individual encounters when anticipating a threatening situation [67]. In CKD, postulated mechanisms for increased susceptibility to anxiety may involve inflammatory processes secondary to uremic toxins, oxidative stress due to increased cytokine production, microvascular damage to the brain, and the involvement of the renin-angiotensin system [19]. However, this postulated mechanism of anxiety is similar to the development of de- pression or cognitive impairment in CKD. Further studies are needed, therefore, to elucidate specific mechanisms.

\section{PREVALENCE OF COGNITIVE IMPAIRMENT IN CKD}

CKD is one of the strongest risk factors for cognitive impairment. The current guidelines used in the diagnosis and management of mild cognitive impairment specify that kidney function should also be assessed as part of the routine neurological workup [5]. In fact, mild cognitive impairment is considered to be a prodromal state that initially occurs in patients with established dementia. The annual rate of progression from mild cognitive impairment to dementia is $1.9 \%$ in ESRD patients [16]. Mild cognitive impairment is more common among patients with stage 1-4 CKD (prevalence, $27 \%$ to $62 \%$ ) than in matched populations without CKD (prevalence, $11 \%$ to $26 \%$ ) $[5,15,68-70]$. The prevalence of mild cognitive impairment increases with the progression of CKD stage [71]. Dementia (Alzheimer's disease, vascular dementia, Lewy body dementia, etc.) is not a specific disease but is, rather, a general term defined as an impaired ability to remember, think, or make decisions that interfere with everyday activities. In the general population, age is a very important risk factor for dementia because the incidence of dementia is very low $(<1 \%)$ in individuals $<65$ years old [72]. However, in young patients with ESRD, the prevalence of cognitive impairment may be higher than that in the general population [73]. Another study showed that the overall age- and sex-specific incidence rates and the cumulative incidence rates of dementia were much higher in ESRD than non-ESRD subjects (10.73 vs. 1.40 per 1,000 person-years and 0.061 vs. 0.017 , respectively, both $p<0.0001$ ) [74]. Age-related chronic diseases, such as cardiovascular disease, high cholesterol, diabetes, and kidney disease, are factors that cause the advancement and rapid progression of dementia [75]. Therefore, CKD itself could be related to the progression and prevalence of dementia.

\section{PATTERN OF COGNITIVE IMPAIRMENT IN CKD}

Cognitive impairment is assessed by analyzing specific cognitive domains, such as attention, memory, visuospatial abil- 
Table 1. Behavior tests and key features of neuropsychiatric disorders in rodents

\begin{tabular}{|c|c|c|c|c|}
\hline Test & Species & Measurement purpose & $\begin{array}{l}\text { Behavioral features } \\
\text { implicated in neuro- } \\
\text { psychiatric disorders }\end{array}$ & Special considerations \\
\hline \multicolumn{5}{|c|}{ Basic motor and sensory function } \\
\hline Open-field test & Rat, Mouse & Locomotor activity & $\begin{array}{l}\text { Hyper locomotion in schizophrenia } \\
\text { [31-34] }\end{array}$ & Can be done acutely \\
\hline Rotarod & Mouse & Locomotor activity & $\begin{array}{l}\text { Decrease in Parkinson's disease } \\
{[35,36]}\end{array}$ & Requires training \\
\hline $\begin{array}{l}\text { Hot plate } \\
\text { (nociception) }\end{array}$ & Rat, Mouse & Thermal nociception & Hyperalgesia [37,38] & $\begin{array}{l}\text { Care must be taken to avoid } \\
\text { injury }\end{array}$ \\
\hline \multicolumn{5}{|l|}{ Learning and memory } \\
\hline Morris water maze & Rat, Mouse & $\begin{array}{l}\text { Spatial learning and } \\
\text { memory }\end{array}$ & $\begin{array}{l}\text { Deficits in cognitive disorders } \\
\text { including dementia and } \\
\text { Alzheimer's disease }[36,39]\end{array}$ & $\begin{array}{l}\text { Requires multiple days of } \\
\text { training }\end{array}$ \\
\hline Barnes maze & Rat, Mouse & $\begin{array}{l}\text { Spatial learning and } \\
\text { memory }\end{array}$ & $\begin{array}{l}\text { Decreased contextual fear memory } \\
\text { in dementia and Alzheimer's } \\
\text { disease }[40,41]\end{array}$ & $\begin{array}{l}\text { Requires multiple days of } \\
\text { training }\end{array}$ \\
\hline Radial arm maze & Rat, Mouse & $\begin{array}{l}\text { Spatial learning and } \\
\text { memory }\end{array}$ & $\begin{array}{l}\text { Deficits in cognitive disorders } \\
\text { including dementia and } \\
\text { Alzheimer's disease }[42,43]\end{array}$ & \\
\hline Object recognition & Rat, Mouse & $\begin{array}{l}\text { Noble object recognition } \\
\text { memory }\end{array}$ & $\begin{array}{l}\text { Deficits in cognitive disorders } \\
\text { including schizophrenia } \\
{[33,34,44]}\end{array}$ & \\
\hline Fear conditioning & Mouse & $\begin{array}{l}\text { Contextual/cued fear } \\
\text { learning and memory, } \\
\text { fear memory extinction }\end{array}$ & $\begin{array}{l}\text { Decreased contextual fear memory } \\
\text { in dementia and Alzheimer's } \\
\text { disease [45-47] }\end{array}$ & $\begin{array}{l}\text { Can be cued or contextual, } \\
\text { requiring different neural } \\
\text { circuits; subject to extinction } \\
\text { and reinstatement }\end{array}$ \\
\hline \multicolumn{5}{|l|}{ Social behavior } \\
\hline Three chamber test & Rat, Mouse & $\begin{array}{l}\text { Social interaction with a } \\
\text { conspecific, preference } \\
\text { for a noble conspecific }\end{array}$ & $\begin{array}{l}\text { Deficits in schizophrenia }[5,31] \text { and } \\
\text { autism spectrum disorder }[48,49]\end{array}$ & $\begin{array}{l}\text { Requires a conspecific } \\
\text { target, isolation housing is } \\
\text { recommended prior to testing }\end{array}$ \\
\hline Sexual behavior & Rat & $\begin{array}{l}\text { Sexual relationship with } \\
\text { cagemates }[50]\end{array}$ & & $\begin{array}{l}\text { Should be assessed during dark } \\
\text { cycle }\end{array}$ \\
\hline Maternal behavior & Rat, Mouse & $\begin{array}{l}\text { Maternal care for } \\
\text { offspring }\end{array}$ & Deficits in schizophrenia $[32,51]$ & \\
\hline Nesting behavior & Rat, Mouse & $\begin{array}{l}\text { Nesting building in home } \\
\text { cage }\end{array}$ & Deficits in schizophrenia $[32,33]$ & \\
\hline \multicolumn{5}{|c|}{ Anxiety and depression-like behaviors } \\
\hline Forced swim test & Rat, Mouse & Depression-like behavior & Decrease in depression $[35,52]$ & $\begin{array}{l}\text { Rats typically require two } \\
\text { swim sessions for sufficient } \\
\text { immobility }\end{array}$ \\
\hline Tail suspension test & Mouse & Depression-like behavior & Decrease in depression $[35,52]$ & \\
\hline Elevated plus maze & Rat, Mouse & $\begin{array}{l}\text { Anxiogenic and anxiolytic } \\
\text { behaviors }\end{array}$ & Anxiety disorder [31,53-55] & $\begin{array}{l}\text { Highly sensitive to prior } \\
\text { handling/testing }\end{array}$ \\
\hline Light/dark box & Mouse & $\begin{array}{l}\text { Anxiogenic and anxiolytic } \\
\text { behaviors }\end{array}$ & Anxiety disorder $[31,53]$ & \\
\hline
\end{tabular}


Table 1. Continued

\begin{tabular}{|c|c|c|c|c|}
\hline Test & Species & Measurement purpose & $\begin{array}{l}\text { Behavioral features } \\
\text { implicated in neuro- } \\
\text { psychiatric disorders }\end{array}$ & Special considerations \\
\hline $\begin{array}{l}\text { Thigmotaxis in } \\
\text { open-field test }\end{array}$ & Rat, Mouse & $\begin{array}{l}\text { Anxiogenic and anxiolytic } \\
\text { behaviors }\end{array}$ & Anxiety disorder [53] & $\begin{array}{l}\text { Responses vary by age, should } \\
\text { be conducted in a soundproof } \\
\text { chamber }\end{array}$ \\
\hline Prepulse inhibition & Rat, Mouse & $\begin{array}{l}\text { Sensory and motor } \\
\text { integration }\end{array}$ & Deficits in schizophrenia [31-34,44] & Similar to acoustic startle \\
\hline \multicolumn{5}{|l|}{ Reward } \\
\hline $\begin{array}{l}\text { Conditioned place } \\
\text { preference }\end{array}$ & Rat, Mouse & $\begin{array}{l}\text { Context-dependent } \\
\text { addiction-like behaviors }\end{array}$ & $\begin{array}{l}\text { Increase in chronic stress and } \\
\text { depression [56] }\end{array}$ & $\begin{array}{l}\text { Requires multiple training } \\
\text { sessions; subject to extinction } \\
\text { and reinstatement }\end{array}$ \\
\hline Sucrose preference & Rat, Mouse & $\begin{array}{l}\text { Depression-like behavior, } \\
\text { anhedonia-like behavior }\end{array}$ & $\begin{array}{c}\text { Decrease in depression }[35,52] \text { and } \\
\text { anhedonia in schizophrenia [33] }\end{array}$ & \\
\hline Self-administration & Rat, Mouse & $\begin{array}{l}\text { Reward seeking behavior, } \\
\text { attention }\end{array}$ & Decrease in depression $[35,52]$ & $\begin{array}{l}\text { Most commonly done in rats; } \\
\text { various reinforcers can be } \\
\text { used; subject to extinction and } \\
\text { reinstatement }\end{array}$ \\
\hline
\end{tabular}

ity, language skills, and execution skills [71]. Recent studies have suggested that the phenotype of cognitive dysfunction in patients with CKD may be different from that in the general population [71]. Attention is defined as the selection of specific information within a sensory channel, i.e., filtering the essential data and ignoring the remaining data. The prefrontal cortex performs this activity, which is modulated by the dopaminergic system. Lizio et al [76]. directly compared CKD-associated dementia with Alzheimer's disease, and they found a more pronounced dysfunction in the frontal cortex of patients with CKD and mild cognitive impairment compared to the general population. The memory storage capacity and the processing of information are impaired in patients with CKD [77]. Some animal studies demonstrated neuronal death in the hippocampus associated with CKD $[62,78,79]$. In addition, CKD was shown to reduce the activity of cholinergic neurons in the nucleus basalis of Meynert [80]. Abnormal interactions occur between these cholinergic neurons and the cortical neurons, causing memory dysfunction in CKD. Griva et al. [81] reported a statistically significant improvement in the memory performance of patients following kidney transplantation. Language skills are also affected in patients with CKD, and this is the only cognitive domain that shows a linear relationship with declining estimated glomerular filtration rate (eGFR) [24]. Although magnetic resonance imaging (MRI) studies did not show any anatomical changes in the cortical language areas [82], poor naming performance was observed in patients with CKD $[83,84]$. Several studies have shown that executive dysfunction occurs in patients with CKD measured by the Trail Making Test type A (TMT-A) and the TMT-B, which test cognitive processing speed $[76,83,85,86]$. Executive dysfunction worsens with a decline in the eGFR [86]. Executive functions are mainly carried out by the frontal lobe, which is thinner in patients with CKD. Cognitive impairment of patients with CKD occurs due to dysregulation of several functional domains of the brain. In fact, it may occur due to the damage caused to multiple cortical regions (particularly the frontal lobe) and subcortical modulatory neurons, especially the adrenergic neurons in the mesencephalon and the cholinergic neurons in the nucleus basalis of Meynert [24]. However, non-CKD dementia is caused by structural abnormalities in different regions of the brain, as revealed by MRI analyses. The differences in the structural brain changes between patients with CKD and non-CKD dementia may be attributed to the different mechanisms of cognitive dysfunction that occur in patients with CKD. 
Light and dark transition test

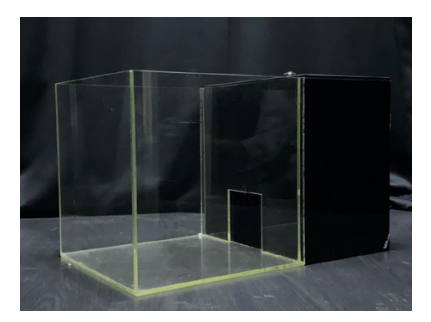

Elevated-plus maze
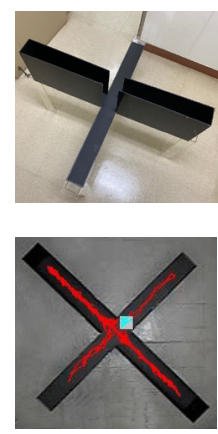

CKD 4 wk

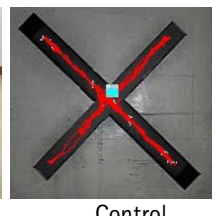

Control

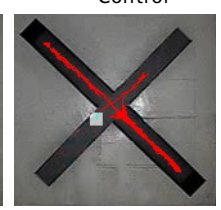

CKD 10 wk

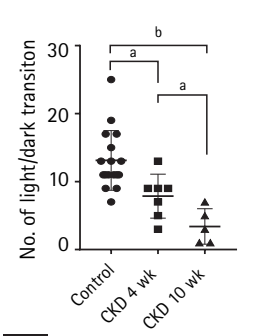

A

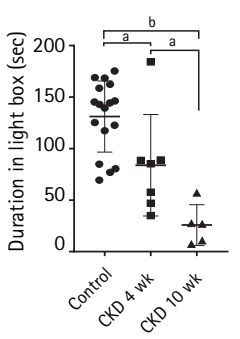

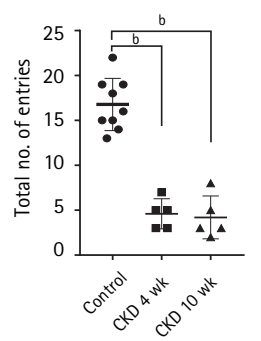

B

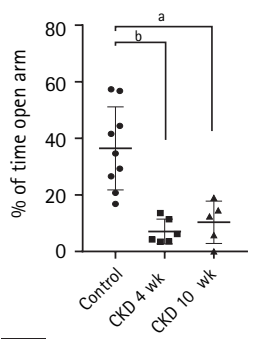

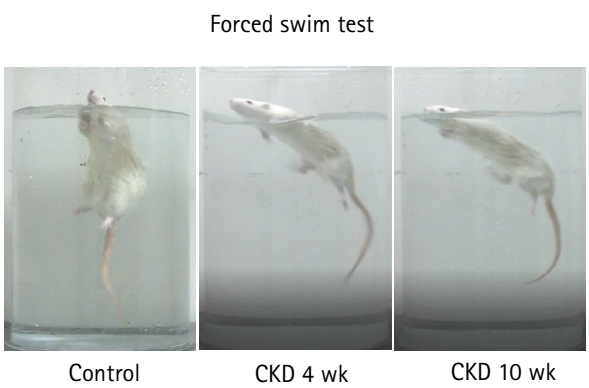
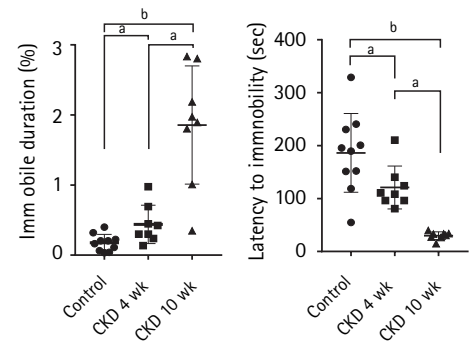

c

Figure 1. Behaviors of depression and anxiety in chronic kidney disease (CKD) rats. (A) The light-dark transition test apparatus consisted of a cage $(30 \times 30 \times 30 \mathrm{~cm})$ divided into two compartments by a black partition with a small opening that allowed the rat to move between the two compartments. One of the compartments was darkened, while the other was brightly illuminated. Rats were placed in the illuminated compartment and allowed to move freely for 5 minutes. The total time spent in the bright compartment was used as an indicator of anti-anxiety behavior. The light/dark transition number and the total time spent in the light compartment by CKD rats were lower than those of controls. (B) The elevated plus-maze test apparatus consisted of an elevated, plus-shaped (+) apparatus with two open arms and two enclosed arms. Rats were placed in an elevated (60 cm above the floor) plus maze that had two opposite open arms (50 $\times 10 \mathrm{~cm}$ each) and two opposite closed arms (50 $\times 10 \mathrm{~cm}$ each); the height of the walls was $50 \mathrm{~cm}$. The number of entries into the maze and the time spent in individual arms were measured for 5 minutes. The percentage of entries into the open arms and the total number of entries in the elevated plus-maze were reduced for CKD rats compared to controls. (C) The forced swimming test was performed to measure depression-like behaviors. Rats were individually placed in a plastic cylinder (50 cm in height, $30 \mathrm{~cm}$ in diameter), which was filled with water $\left(23^{\circ} \mathrm{C} \pm 3^{\circ} \mathrm{C}\right)$. Their behavior was observed for 5 minutes, and their immobility time was calculated. The time spent immobile was taken as an indicator of depression-like behavior. During the forced swimming test, the percentages of immobility were higher for CKD rats than controls. A decreased latency to immobility was observed in CKD rats. Data are presented as the mean \pm standard error of the mean. Modified from Yu et al. [62]. ${ }^{a} p<0.01,{ }^{b} p<0.001$, one-way analysis of variance.

\section{MECHANISM OF COGNITIVE IMPAIRMENT IN CKD}

The mechanism of cognitive impairment in CKD is not well understood. Genetic factors lead to the pathogenesis of cognitive dysfunction in pediatric patients with CKD $[71,87]$. However, vascular injury and uremic toxins are suspected to induce cognitive impairment in adult patients with CKD [10]. Atherosclerosis and endothelial dysfunction are common conditions in patients with CKD. The kidney and the brain have "strain vessels," i.e., afferent arterioles in the kidney and perforating arterioles in the brain. These vessels are short in length, because small arterioles branch out of very large arteries that autoregulate tissue perfusion [88]. The anatomical vascular systems are similar in both of these organs, which may be susceptible to the traditional risk factors, i.e., hypertension, diabetes, hyperlipidemia, and obesity [14]. As many risk factors are involved in the development of CKD and vascular dysfunction, vascular factors could also be involved in the development of cognitive impairment in patients with CKD. In the general population, reduced cerebral blood flow impairs neural activity, which is involved in the pathogenesis of cognitive impairment. However, the global cerebral blood flow was found to be higher in CKD patients than in healthy individuals, which does not support the more general notion of vascular dysfunction in 
Table 2. Behavior changes in chronic kidney disease animal models

\begin{tabular}{|c|c|c|c|c|c|}
\hline Study & CKD model & Species & CKD duration & Behavior tests & Key findings \\
\hline $\begin{array}{l}\text { Bobot et al. (2020) } \\
\text { [63] }\end{array}$ & $\begin{array}{l}\text { Adenin rich diet } \\
\text { rat with drinking } \\
\text { indoxyl sulfate }\end{array}$ & $\begin{array}{l}\text { Sprague- } \\
\text { Dawley rats }\end{array}$ & 4 weeks & $\begin{array}{l}\text { Novel object } \\
\text { recognition test } \\
\text { Object location task }\end{array}$ & $\begin{array}{l}\text { In chronic kidney disease (CKD) } \\
\text { rat, aryl hydrocarbon receptor } \\
\text { activation by indoxyl sulfate leads } \\
\text { the blood-brain barrier disruption. } \\
\text { Increase of indoxyl sulfate } \\
\text { was associated with cognition } \\
\text { impairment. }\end{array}$ \\
\hline $\begin{array}{l}\text { Chillon et al. (2014) } \\
\text { [9] }\end{array}$ & 5/6 Nephrectomy & C57BL/6J mice & $\begin{array}{l}6 \text { and } 10 \\
\text { weeks }\end{array}$ & $\begin{array}{l}\text { The open filed test } \\
\text { Dark/light box test } \\
\text { Elevated maze test } \\
\text { Y maze } \\
\text { Prehensile test }\end{array}$ & $\begin{array}{l}\text { Anxiety did not increase in CKD. } \\
\text { Recognition was impaired after } 10 \\
\text { weeks. }\end{array}$ \\
\hline $\begin{array}{l}\text { Karbowska et al. } \\
\text { (2020) [64] }\end{array}$ & $\begin{array}{l}\text { Indoxyl sulfate (100 } \\
\text { mg/kg) drinking }\end{array}$ & $\begin{array}{l}\text { Albino Wistar } \\
\text { rats }\end{array}$ & 4 weeks & $\begin{array}{l}\text { Open field with } \\
\text { illuminated center } \\
\text { test } \\
\text { Elevated plus maze } \\
\text { test } \\
\text { Chimney test } \\
\text { T maze test } \\
\text { Splash test }\end{array}$ & $\begin{array}{l}\text { The highest accumulation of } \\
\text { indoxyl sulfate was observed in the } \\
\text { brainstem. Indoxyl sulfate leads } \\
\text { to behavior alterations involving } \\
\text { apathetic behavior, increased } \\
\text { stress sensitivity, and reduced } \\
\text { locomotor and exploratory activity }\end{array}$ \\
\hline Lv et al. (2016) [65]. & 5/6 Nephrectomy & $\begin{array}{l}\text { Sprague- } \\
\text { Dawley rats }\end{array}$ & 8 weeks & $\begin{array}{l}\text { Morris water-maze } \\
\text { test }\end{array}$ & $\begin{array}{l}\text { In chronic renal failure rats, the } \\
\text { escape latency was increased } \\
\text { significantly (Morris water-maze } \\
\text { test) and the protein and mRNA } \\
\text { expression of ghrelin and growth } \\
\text { hormone secretagogue receptor in } \\
\text { hippocampus was also increased } \\
\text { significantly }\end{array}$ \\
\hline $\begin{array}{l}\text { Mazumder et al. } \\
\text { (2016) [61] }\end{array}$ & $\begin{array}{l}\text { Adenin rich diet } \\
\text { mice }\end{array}$ & $\begin{array}{l}\text { Swiss albino } \\
\text { mice }\end{array}$ & 4 weeks & $\begin{array}{l}\text { Forced swim test } \\
\text { Dark/light box test } \\
\text { Neurological severity } \\
\text { Exit circle } \\
\text { Seeking behavior } \\
\text { Monparessi/ } \\
\text { hemiparesis } \\
\text { Paw grip strength } \\
\text { Straight walk } \\
\text { Startle reflex } \\
\text { Beam balancing } \\
\text { Beam walk } \\
\text { Round stick } \\
\text { balancing }\end{array}$ & $\begin{array}{l}\text { In CKD rat, Evans blue dye } \\
\text { extravasation was found to occur } \\
\text { in the brain, which signifies } \\
\text { disruption of blood-brain barrier. } \\
\text { Motor behavioral abnormalities, } \\
\text { depression like and anxiolytic } \\
\text { behavior and increase in } \\
\text { neurologic severity were prevalent } \\
\text { in mice with CKD. }\end{array}$ \\
\hline
\end{tabular}

\begin{tabular}{|c|c|c|c|c|c|}
\hline $\begin{array}{l}\text { Renczes et al. (2020) } \\
\text { [66] }\end{array}$ & 5/6 Nephrectomy & Wistar rats & $\begin{array}{l}2,4, \text { and } 6 \\
\text { months }\end{array}$ & $\begin{array}{l}\text { Open-field, } \\
\text { Light-dark box } \\
\text { Novel object } \\
\text { recognition }\end{array}$ & $\begin{array}{l}\text { Chronic renal failure rats did not } \\
\text { significantly influence either } \\
\text { locomotor activity, or anxiety-like } \\
\text { behavior, or memory functions. }\end{array}$ \\
\hline
\end{tabular}




\section{Table 2. Continued}

\begin{tabular}{|c|c|c|c|c|c|}
\hline Study & CKD model & Species & CKD duration & Behavior tests & Key findings \\
\hline $\begin{array}{l}\text { Topczewska-Bruns et } \\
\text { al. (2001) [58] }\end{array}$ & $\begin{array}{l}\text { Moderate chronic } \\
\text { renal insufficiency: } \\
\text { left nephrectomy } \\
\text { with right } 60 \% \\
\text { decortication, } \\
\text { Severe chronic } \\
\text { renal insufficiency: } \\
\text { left nephrectomy } \\
\text { with right } 80 \% \\
\text { decortication }\end{array}$ & Wistar rats & $\begin{array}{l}1 \text { and } 2 \\
\text { months }\end{array}$ & Open filed test & $\begin{array}{l}\text { The open field test have shown a } \\
\text { marked decrease in locomotor, } \\
\text { exploratory and emotional activity } \\
\text { of the animals suffering from } \\
\text { chronic renal insufficiency. }\end{array}$ \\
\hline Yu et al. (2021) [62] & 5/6 Nephrectomy & $\begin{array}{l}\text { Sprague- } \\
\text { Dawley rats }\end{array}$ & $\begin{array}{l}4 \text { and } 10 \\
\text { weeks }\end{array}$ & $\begin{array}{l}\text { Open-field, } \\
\text { Elevated plus-maze, } \\
\text { Light-dark transition } \\
\text { Forced swim test }\end{array}$ & $\begin{array}{l}\text { The level of anxiety and depression- } \\
\text { like behaviors increased in the 10- } \\
\text { week CKD rat models compared } \\
\text { with the 4-week rat models. } \\
\text { In the recording of local field } \\
\text { potentials, the power of delta (1-4 } \\
\mathrm{Hz} \text { ), theta (4-7 Hz), and alpha } \\
\text { rhythm (7-12 Hz) was significantly } \\
\text { increased in the hippocampus of } \\
\text { CKD rats. }\end{array}$ \\
\hline
\end{tabular}

patients with CKD [89]. Prior to peritoneal dialysis, ESRD patients were shown to have cerebral hyperperfusion with reduced execution function [90]. Increased cerebral blood flow probably occurs due to anemia in patients with CKD $[90,91]$. This discrepancy makes it difficult to apply directly the mechanism of cognitive impairment determined in the general population to patients with CKD.

In patients with CKD, vascular injury can lead to white matter lesions, silent infarction, and cerebral microbleeds. Leukoaraiosis is a pathological appearance of the brain white matter, which is thought to be due to perfusion abnormalities within the arterioles that perforate through the deep brain structures. Leukoaraiosis is thought to represent ischemia and is associated with increased risk of stroke and dementia $[92,93]$. The prevalence of leukoaraiosis is higher in patients with CKD than in the general population [94].

Uremic toxins accumulate in the body fluids of patients with progressive CKD, and have a direct impact on the development of cerebrovascular disease. Recent studies have reported that uremic toxins cause cognitive impairment in patients with CKD. A recent review article established that uremic toxins, such as uric acid, indoxyl sulfate, $\mathrm{p}$-cresyl sul-

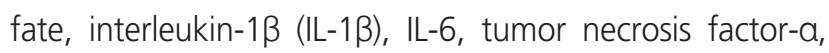
and parathyroid hormone, are likely to have an impact on the CNS, although the underlying mechanisms have yet to be elucidated [95]. In addition, guanidine compounds, asymmetric dimethylarginine, fibroblast growth factor 23, excessive phosphate, and indoxyl sulfate have also been considered potential uremic neurotoxins.

Indoxyl sulfate is a protein-bound uremic toxin, which is also known to be a renal and vascular toxin as it causes nephrotoxicity, especially in tubular cells, and inhibits the proliferation of endothelial cells; thus, indoxyl sulfate induces free radicals $[96,97]$. In endothelial cells, aryl hydrocarbon receptor (AhR) may be the receptor of indoxyl sulfate. When indoxyl sulfate activates AhR, it causes endothelial dysfunction by inducing endothelial inflammation and an increase in oxidative stress. This leads to the development of a procoagulant state. Moreover, AhR is widely expressed in the CNS, and activated AhR was shown to have detrimental effects on cognitive functions. Recent studies suggested that indoxyl sulfate induces neurotoxicity via the proposed mechanism shown in Fig. 2. Adesso et al. [98] reported that indoxyl sulfate causes inflammation and oxidative stress in primary cells of the CNS by activating nuclear factor-KB (NF$K B)$ and $A h R s$, resulting in the induction of neuronal death. Indoxyl sulfate plays a role in apoptosis via inhibition of the mitogen-activated protein kinase (MAPK) pathway in hu- 


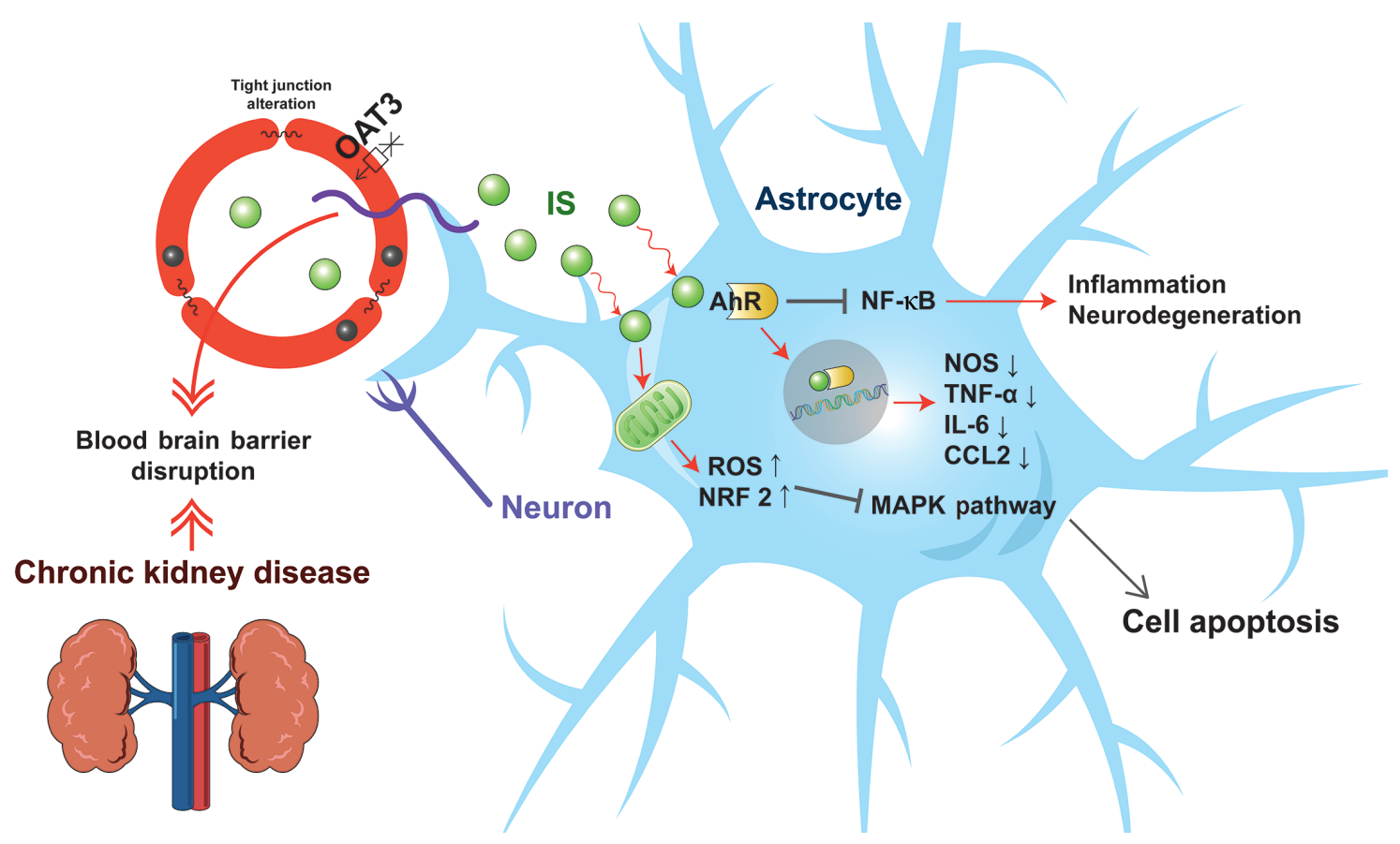

Figure 2. Proposed scheme of indoxyl sulfate-induced neurotoxicity. Indoxyl sulfate disrupts the integrity of the blood-brain barrier. In addition, indoxyl sulfate inhibits organic anion transporter 3 (OAT3) and efflux transport of endothelial cells, resulting in the accumulation of indoxyl sulfate in the brain. Furthermore, indoxyl sulfate increases reactive oxygen species (ROS) in astrocytes, inhibiting the mitogen-activated protein kinase (MAPK) pathway and inducing apoptosis. Moreover, indoxyl sulfate binds with aryl hydrocarbon receptor (AhR), and activates the signaling of AhR in astrocytes. The activated AhR inhibits the transcription of nitric oxide synthase (NOS), tumor necrosis factor-a (TNF-a), interleukin 6 (IL-6), and C-C motif chemokine ligand 2 (CCL2), which show antiinflammatory effects. Finally, indoxyl sulfate suppresses nuclear factor-KB (NF-KB) signals in astrocytes, which promote inflammation and neurodegeneration in the CNS. NRF2, nuclear factor erythroid 2-related factor 2.

man astrocytes under conditions of oxidative stress [99]. Bobot et al. [63] reported that rats fed an adenine-rich diet with drinking water containing indoxyl sulfate showed an increased serum concentration of indoxyl sulfate and stronger impairment of cognition and increased permeability of the blood-brain barrier (BBB). Consequently, uremic toxins accumulated in the brain as the BBB was disrupted due to increased indoxyl sulfate concentration. The glymphatic system is a waste clearance system in the CNS, which is formed by astroglial cells that efficiently eliminate soluble proteins and various metabolites from the CNS. Intriguingly, the glymphatic system functions mainly during sleep, and is largely disengaged during wakefulness. Sleep disturbances are common in patients with CKD. Further studies are required to determine how uremic toxins and/or CKD influence the glymphatic system, which can suppress the clearance of uremic toxins and $\beta$-amyloid.

\section{CONCLUSIONS}

Clinical studies have consistently established that there is a relationship between CKD and emotional/cognitive changes. Genetic factors, inflammation, cerebrovascular disease, vascular factors, and uremic toxins may be associated with the development and progression of cognitive changes in patients with CKD. Radiological studies have elucidated the different mechanisms of CKD dementia and compared them with the characteristics of non-CKD dementia. Furthermore, animal studies have established the mechanism underlying the brain damage caused by CKD. However, discrepancies occurred between behavioral tests, and further studies are required to determine the detailed mechanisms. Finally, research should also focus on identification of potential therapeutic targets to prevent changes in the brains of patients with CKD. 


\section{Conflict of interest}

No potential conflict of interest relevant to this article was reported.

\section{Acknowledgments}

This work was supported by the Basic Science Research Program (2021R1F1A1060352 and 2017R1D1A1B05036195) through the National Research Foundation of Korea funded by the Ministry of Education and the Soonchunhyang University Research Fund.

\section{REFERENCES}

1. Park Jl, Baek H, Jung HH. Prevalence of chronic kidney disease in Korea: the Korean National Health and Nutritional Examination Survey 2011-2013. J Korean Med Sci 2016;31:915923.

2. Kim $Y, \operatorname{Han} X, A h n Y$, et al. Clinical characteristics of spontaneous coronary artery dissection in young female patients with acute myocardial infarction in Korea. Korean J Intern Med 2021;36:106-113.

3. Kang Y, Choi HY, Kwon YE, et al. Clinical outcomes among hemodialysis patients with atrial fibrillation: a Korean nationwide population-based study. Kidney Res Clin Pract 2021;40:99-108.

4. Jung SW, Moon JY. The role of inflammation in diabetic kidney disease. Korean J Intern Med 2021;36:753-766.

5. Albert MS, DeKosky ST, Dickson D, et al. The diagnosis of mild cognitive impairment due to Alzheimer's disease: recommendations from the National Institute on Aging-Alzheimer's Association workgroups on diagnostic guidelines for Alzheimer's disease. Alzheimers Dement 2011;7:270-279.

6. Basile DP, Ullah MM, Collet JA, Mehrotra P. T helper 17 cells in the pathophysiology of acute and chronic kidney disease. Kidney Res Clin Pract 2021;40:12-28.

7. Kim SM, Song $\mathbb{I H}$. The clinical impact of gut microbiota in chronic kidney disease. Korean J Intern Med 2020;35:13051316.

8. Nath M, Agarwal A. New insights into the role of heme oxygenase-1 in acute kidney injury. Kidney Res Clin Pract 2020;39:387-401.

9. Chillon JM, Brazier F, Bouquet P, Massy ZA. Neurological disorders in a murine model of chronic renal failure. Toxins (Basel) 2014;6:180-193.

10. Bugnicourt JM, Godefroy O, Chillon JM, Choukroun G, Massy
ZA. Cognitive disorders and dementia in CKD: the neglected kidney-brain axis. J Am Soc Nephrol 2013;24:353-363.

11. Tsuruya K, Yoshida H. Brain atrophy and cognitive impairment in chronic kidney disease. Contrib Nephrol 2018;196:27-36.

12. Zalai D, Szeifert L, Novak M. Psychological distress and depression in patients with chronic kidney disease. Semin Dial 2012;25:428-438.

13. Jabbari B, Vaziri ND. The nature, consequences, and management of neurological disorders in chronic kidney disease. Hemodial Int 2018;22:150-160.

14. Tanaka S, Okusa MD. Crosstalk between the nervous system and the kidney. Kidney Int 2020;97:466-476.

15. Hobson P, Lewis A, Nair H, Wong S, Kumwenda M. How common are neurocognitive disorders in patients with chronic kidney disease and diabetes?: results from a cross-sectional study in a community cohort of patients in North Wales, UK. BMJ Open 2018;8:e023520.

16. Brodski J, Rossell SL, Castle DJ, Tan EJ. A systematic review of cognitive impairments associated with kidney failure in adults before natural age-related changes. J Int Neuropsychol Soc 2019;25:101-114.

17. Murtagh FE, Addington-Hall J, Higginson IJ. The prevalence of symptoms in end-stage renal disease: a systematic review. Adv Chronic Kidney Dis 2007;14:82-99.

18. Gonzalez AM, Gutman T, Lopez-Vargas P, et al. Patient and caregiver priorities for outcomes in CKD: a multinational nominal group technique study. Am J Kidney Dis 2020;76:679689.

19. Huang CW, Wee PH, Low LL, et al. Prevalence and risk factors for elevated anxiety symptoms and anxiety disorders in chronic kidney disease: a systematic review and meta-analysis. Gen Hosp Psychiatry 2021;69:27-40.

20. Loosman WL, Rottier MA, Honig A, Siegert CE. Association of depressive and anxiety symptoms with adverse events in Dutch chronic kidney disease patients: a prospective cohort study. BMC Nephrol 2015;16:155.

21. Ng HJ, Tan WJ, Mooppil N, Newman S, Griva K. Prevalence and patterns of depression and anxiety in hemodialysis patients: a 12-month prospective study on incident and prevalent populations. Br J Health Psychol 2015;20:374-395.

22. Waraich P, Goldner EM, Somers JM, Hsu L. Prevalence and incidence studies of mood disorders: a systematic review of the literature. Can J Psychiatry 2004;49:124-138.

23. Palmer S, Vecchio M, Craig JC, et al. Prevalence of depression in chronic kidney disease: systematic review and meta-analysis of observational studies. Kidney Int 2013;84:179-191. 
24. Berger I, Wu S, Masson P, et al. Cognition in chronic kidney disease: a systematic review and meta-analysis. BMC Med 2016;14:206.

25. Watnick S, Wang PL, Demadura T, Ganzini L. Validation of 2 depression screening tools in dialysis patients. Am J Kidney Dis 2005;46:919-924.

26. Hedayati SS, Bosworth HB, Kuchibhatla M, Kimmel PL, Szczech LA. The predictive value of self-report scales compared with physician diagnosis of depression in hemodialysis patients. Kidney Int 2006;69:1662-1668.

27. Hedayati SS, Minhajuddin AT, Toto RD, Morris DW, Rush AJ. Validation of depression screening scales in patients with CKD. Am J Kidney Dis 2009;54:433-439.

28. Oberg BP, McMenamin E, Lucas FL, et al. Increased prevalence of oxidant stress and inflammation in patients with moderate to severe chronic kidney disease. Kidney Int 2004;65:10091016.

29. Kim AJ, Ro H, Kim H, et al. Elevated levels of soluble ST2 but not galectin-3 are associated with increased risk of mortality in hemodialysis patients. Kidney Res Clin Pract 2021;40:109119.

30. Katon WJ. Epidemiology and treatment of depression in patients with chronic medical illness. Dialogues Clin Neurosci 2011;13:7-23.

31. Kim SW, Seo M, Kim DS, et al. Knockdown of phospholipase C- $\beta 1$ in the medial prefrontal cortex of male mice impairs working memory among multiple schizophrenia endophenotypes. J Psychiatry Neurosci 2015;40:78-88.

32. Koh HY, Kim D, Lee J, Lee S, Shin HS. Deficits in social behavior and sensorimotor gating in mice lacking phospholipase Cbeta1. Genes Brain Behav 2008;7:120-128.

33. Zhang $N$, Zhong $P$, Shin SM, et al. S-SCAM, a rare copy number variation gene, induces schizophrenia-related endophenotypes in transgenic mouse model. J Neurosci 2015;35:18921904.

34. McOmish CE, Burrows EL, Howard M, Hannan AJ. PLC-beta1 knockout mice as a model of disrupted cortical development and plasticity: behavioral endophenotypes and dysregulation of RGS4 gene expression. Hippocampus 2008;18:824-834.

35. Yang Y, Cui Y, Sang K, et al. Ketamine blocks bursting in the lateral habenula to rapidly relieve depression. Nature 2018;554:317-322.

36. Park JH, Ju YH, Choi JW, et al. Newly developed reversible MAO-B inhibitor circumvents the shortcomings of irreversible inhibitors in Alzheimer's disease. Sci Adv 2019;5:eaav0316.

37. MacDonald DI, Sikandar S, Weiss J, et al. A central mechanism of analgesia in mice and humans lacking the sodium channel $\mathrm{Na}_{\mathrm{V}}$ 1.7. Neuron 2021;109:1497-1512.

38. McCormack K, Prather P, Chapleo C. Some new insights into the effects of opioids in phasic and tonic nociceptive tests. Pain 1998;78:79-98.

39. D'Hooge R, De Deyn PP. Applications of the Morris water maze in the study of learning and memory. Brain Res Brain Res Rev 2001;36:60-90.

40. Webster SJ, Bachstetter AD, Nelson PT, Schmitt FA, Van Eldik $\sqcup$. Using mice to model Alzheimer's dementia: an overview of the clinical disease and the preclinical behavioral changes in 10 mouse models. Front Genet 2014;5:88.

41. Gawel K, Gibula E, Marszalek-Grabska M, Filarowska J, Kotlinska JH. Assessment of spatial learning and memory in the Barnes maze task in rodents-methodological consideration. Naunyn Schmiedebergs Arch Pharmacol 2019;392:1-18.

42. Olton DS. The radial arm maze as a tool in behavioral pharmacology. Physiol Behav 1987;40:793-797.

43. Wahl D, Coogan SC, Solon-Biet SM, et al. Cognitive and behavioral evaluation of nutritional interventions in rodent models of brain aging and dementia. Clin Interv Aging 2017;12:1419-1428.

44. McOmish CE, Burrows E, Howard M, et al. Phospholipase C-beta1 knockout mice exhibit endophenotypes modeling schizophrenia which are rescued by environmental enrichment and clozapine administration. Mol Psychiatry 2008;13:661672.

45. Kim HY, Kim HV, Jo S, et al. EPPS rescues hippocampus-dependent cognitive deficits in APP/PS1 mice by disaggregation of amyloid- $\beta$ oligomers and plaques. Nat Commun 2015;6:8997.

46. Jo S, Yarishkin O, Hwang YJ, et al. GABA from reactive astrocytes impairs memory in mouse models of Alzheimer's disease. Nat Med 2014;20:886-896.

47. Likhtik E, Stujenske JM, Topiwala MA, Harris AZ, Gordon JA. Prefrontal entrainment of amygdala activity signals safety in learned fear and innate anxiety. Nat Neurosci 2014;17:106113.

48. Won H, Lee HR, Gee HY, et al. Autistic-like social behaviour in Shank2-mutant mice improved by restoring NMDA receptor function. Nature 2012;486:261-265.

49. Wang X, McCoy PA, Rodriguiz RM, et al. Synaptic dysfunction and abnormal behaviors in mice lacking major isoforms of Shank3. Hum Mol Genet 2011;20:3093-3108.

50. Yang Y, Li H, Ward R, Gao L, Wei JF, Xu TR. Novel oxytocin receptor agonists and antagonists: a patent review (2002-2013). 
Expert Opin Ther Pat 2014;24:29-46.

51. Li M. Antipsychotic drugs on maternal behavior in rats. Behav Pharmacol 2015;26:616-626.

52. Cui Y, Yang Y, Ni Z, et al. Astroglial Kir4.1 in the lateral habenula drives neuronal bursts in depression. Nature 2018;554:323-327.

53. Shin J, Gireesh G, Kim SW, et al Phospholipase C beta 4 in the medial septum controls cholinergic theta oscillations and anxiety behaviors. J Neurosci 2009;29:15375-15385.

54. Padilla-Coreano N, Bolkan SS, Pierce GM, et al. Direct ventral hippocampal-prefrontal input is required for anxiety-related neural activity and behavior. Neuron 2016;89:857-866.

55. Adhikari A, Topiwala MA, Gordon JA. Synchronized activity between the ventral hippocampus and the medial prefrontal cortex during anxiety. Neuron 2010;65:257-269.

56. Bali A, Randhawa PK, Jaggi AS. Stress and opioids: role of opioids in modulating stress-related behavior and effect of stress on morphine conditioned place preference. Neurosci Biobehav Rev 2015;51:138-150.

57. Ali BH, Ziada A, Al Husseni I, Beegam S, Nemmar A. Motor and behavioral changes in rats with adenine-induced chronic renal failure: influence of acacia gum treatment. Exp Biol Med (Maywood) 2011;236:107-112.

58. Topczewska-Bruns J, Tankiewicz A, Pawlak D, Buczko W. Behavioral changes in the course of chronic renal insufficiency in rats. Pol J Pharmacol 2001;53:263-269.

59. Ballesta JJ, del Pozo C, Castello-Banyuls J, Faura CC. Selective down-regulation of a $4 \beta 2$ neuronal nicotinic acetylcholine receptors in the brain of uremic rats with cognitive impairment. Exp Neurol 2012;236:28-33.

60. Tothova L, Babickova J, Borbelyova V, Filova B, Sebekova $K$, Hodosy J. Chronic renal insufficiency does not induce behavioral and cognitive alteration in rats. Physiol Behav 2015;138:133-140.

61. Mazumder MK, Giri A, Kumar S, Borah A. A highly reproducible mice model of chronic kidney disease: evidences of behavioural abnormalities and blood-brain barrier disruption. Life Sci 2016;161:27-36.

62. Yu YH, Kim SW, Park DK, Song HY, Kim DS, Gil HW. Altered emotional phenotypes in chronic kidney disease following 5/6 nephrectomy. Brain Sci 2021;11:882.

63. Bobot M, Thomas L, Moyon A, et al. Uremic toxic blood-brain barrier disruption mediated by AhR activation leads to cognitive impairment during experimental renal dysfunction. J Am Soc Nephrol 2020;31:1509-1521.

64. Karbowska M, Hermanowicz JM, Tankiewicz-Kwedlo A, et al.
Neurobehavioral effects of uremic toxin-indoxyl sulfate in the rat model. Sci Rep 2020;10:9483.

65. Lv Z, Gao J, Wang L, et al. Uremia-caused changes of ghrelin system in hippocampus may be associated with impaired cognitive function of hippocampus. Int Urol Nephrol 2016;48:807-815.

66. Renczes E, Maronek M, Gaal Kovalcikova A, Vavrincova-Yaghi D, Tothova L, Hodosy J. Behavioral changes during development of chronic kidney disease in rats. Front Med (Lausanne) 2020;6:311.

67. Goh ZS, Griva K. Anxiety and depression in patients with endstage renal disease: impact and management challenges: a narrative review. Int J Nephrol Renovasc Dis 2018;11:93-102.

68. Otobe $Y$, Hiraki K, Hotta C, et al. Mild cognitive impairment in older adults with pre-dialysis patients with chronic kidney disease: prevalence and association with physical function. Nephrology (Carlton) 2019;24:50-55.

69. Nicholas P, Green T, Purtell L, Bonner A. A cross-sectional study exploring cognitive impairment in kidney failure. J Ren Care 2021 Jul 6 [Epub]. https://doi.org/10.1111/jorc.12393.

70. Thancharoen O, Waleekhachonloet O, Limwattananon C, Anutrakulchai S. Cognitive impairment, quality of life and healthcare utilization in patients with chronic kidney disease stages 3 to 5. Nephrology (Carlton) 2020;25:625-633.

71. Viggiano D, Wagner CA, Martino G, et al. Mechanisms of cognitive dysfunction in CKD. Nat Rev Nephrol 2020;16:452469.

72. van der Flier WM, Scheltens P. Epidemiology and risk factors of dementia. J Neurol Neurosurg Psychiatry 2005;76(Suppl 5): $v 2-v 7$.

73. Kurella Tamura M, Yaffe K. Dementia and cognitive impairment in ESRD: diagnostic and therapeutic strategies. Kidney Int 2011;79:14-22.

74. Kuo YT, Li CY, Sung JM, et al. Risk of dementia in patients with end-stage renal disease under maintenance dialysis: a nationwide population-based study with consideration of competing risk of mortality. Alzheimers Res Ther 2019;11:31.

75. Sheladia S, Reddy PH. Age-related chronic diseases and Alzheimer's disease in Texas: a Hispanic focused study. J Alzheimers Dis Rep 2021;5:121-133.

76. Lizio R, Babiloni C, Del Percio C, et al. Different abnormalities of cortical neural synchronization mechanisms in patients with mild cognitive impairment due to Alzheimer's and chronic kidney diseases: an EEG study. J Alzheimers Dis 2018;65:897915.

77. Jones DJ, Harris JP, Vaux E, Hadid R, Kean R, Butler LT. The 
nature of impairments of memory in patients with end-stage renal disease (ESRD). Physiol Behav 2015;147:324-333.

78. Kim JW, Ha GY, Jung YW. Chronic renal failure induces cell death in rat hippocampal CA1 via upregulation of aCaMKII/ NR2A synaptic complex and phosphorylated GluR1-containing AMPA receptor cascades. Kidney Res Clin Pract 2014;33:132138.

79. Lee JH, Yoon YM, Lee SH. TUDCA-treated mesenchymal stem cells protect against ER stress in the hippocampus of a murine chronic kidney disease model. Int J Mol Sci 2019;20:613.

80. Mazumder MK, Paul R, Bhattacharya P, Borah A. Neurological sequel of chronic kidney disease: from diminished Acetylcholinesterase activity to mitochondrial dysfunctions, oxidative stress and inflammation in mice brain. Sci Rep 2019;9:3097.

81. Griva K, Thompson D, Jayasena D, Davenport A, Harrison $M$, Newman SP. Cognitive functioning pre- to post-kidney transplantation: a prospective study. Nephrol Dial Transplant 2006;21:3275-3282.

82. Song SH, Kim IJ, Kim SJ, Kwak IS, Kim YK. Cerebral glucose metabolism abnormalities in patients with major depressive symptoms in pre-dialytic chronic kidney disease: statistical parametric mapping analysis of F-18-FDG PET, a preliminary study. Psychiatry Clin Neurosci 2008;62:554-561.

83. Puy L, Bugnicourt JM, Liabeuf $S$, et al. Cognitive impairments and dysexecutive behavioral disorders in chronic kidney disease. J Neuropsychiatry Clin Neurosci 2018;30:310-317.

84. Yaffe K, Ackerson L, Kurella Tamura M, et al. Chronic kidney disease and cognitive function in older adults: findings from the chronic renal insufficiency cohort cognitive study. J Am Geriatr Soc 2010;58:338-345.

85. Burns CM, Knopman DS, Tupper DE, et al. Prevalence and risk of severe cognitive impairment in advanced chronic kidney disease. J Gerontol A Biol Sci Med Sci 2018;73:393-399.

86. Lee $S$, Shimada $H$, Park $H$, et al. The association between kidney function and cognitive decline in community-dwelling, elderly Japanese people. J Am Med Dir Assoc 2015;16:349.

87. Hildebrandt F. Genetic kidney diseases. Lancet 2010;375:12871295.

88. Koren-Morag N, Goldbourt U, Tanne D. Renal dysfunction and risk of ischemic stroke or TIA in patients with cardiovascular disease. Neurology 2006;67:224-228.

89. Jiang $X L$, Wen JQ, Zhang $\amalg$, et al. Cerebral blood flow changes in hemodialysis and peritoneal dialysis patients: an arterial-spin labeling MR imaging. Metab Brain Dis 2016;31:929936.

90. Cheng BC, Chen PC, Chen PC, et al. Decreased cerebral blood flow and improved cognitive function in patients with end-stage renal disease after peritoneal dialysis: an arterial spin-labelling study. Eur Radiol 2019;29:1415-1424.

91. Liu HS, Hartung EA, Jawad AF, et al. Regional cerebral blood flow in children and young adults with chronic kidney disease. Radiology 2018;288:849-858.

92. Weiner DE, Bartolomei K, Scott T, et al. Albuminuria, cognitive functioning, and white matter hyperintensities in homebound elders. Am J Kidney Dis 2009;53:438-447.

93. Debette S, Markus HS. The clinical importance of white matter hyperintensities on brain magnetic resonance imaging: systematic review and meta-analysis. BMJ 2010;341:c3666.

94. Khatri M, Wright CB, Nickolas TL, et al. Chronic kidney disease is associated with white matter hyperintensity volume: the Northern Manhattan Study (NOMAS). Stroke 2007;38:31213126.

95. Watanabe K, Watanabe T, Nakayama M. Cerebro-renal interactions: impact of uremic toxins on cognitive function. Neurotoxicology 2014;44:184-193.

96. Niwa T. Indoxyl sulfate is a nephro-vascular toxin. J Ren Nutr 2010;20(5 Suppl):S2-S6

97. Dou L, Sallee M, Cerini C, et al. The cardiovascular effect of the uremic solute indole-3 acetic acid. J Am Soc Nephrol 2015;26:876-887.

98. Adesso S, Magnus T, Cuzzocrea S, et al. Indoxyl sulfate affects glial function increasing oxidative stress and neuroinflammation in chronic kidney disease: interaction between astrocytes and microglia. Front Pharmacol 2017;8:370.

99. Lin YT, Wu PH, Tsai YC, et al. Indoxyl sulfate induces apoptosis through oxidative stress and mitogen-activated protein kinase signaling pathway inhibition in human astrocytes. J Clin Med 2019;8:191. 